\title{
An Interview with Fred Frith: The Teaching of Contemporary Improvisation
}

\author{
Charity Chan, Mills College
}

Formed in the fall of 2004, the contemporary improvisation program at Mills College is one of the few graduate programs in the United States dedicated solely to the study of improvisation apart from any specific focus such as jazz. As the brainchild of guitarist/improviser/composer Fred Frith, the program grew exponentially in its first two years. With a long history of performing and teaching in the field of improvisation, Fred Frith is remarkably positioned not only to initiate such a program, but also to talk about pedagogies of improvisational music.

Based on a core curriculum of academic and performance courses, the program includes a number of annual workshops conducted by visiting composers, performers, and improvisers such as Maggie Nicols, Joëlle Léandre, Frank Gratkowski, Jean Derome, Pierre Tanguay, Janet Feder, Lê Quan Ninh, Frédéric Blondy, and Marque Gilmore. Course work includes intensive large and small group ensemble playing as well as studying scholarly discourse surrounding improvisation and contemporary music. In the academic year 2007-08, Mills College faculty will be joined by Roscoe Mitchell (Darius Milhaud Chair in Composition) and Zeena Parkins (visiting faculty).

The Music Department at Mills College is distinctive in a number of ways. It has a long history of being at the forefront of experimental and contemporary music and is an all-women's college at the undergraduate level. For Professor Frith, it is a priority that the Music Improvisation Ensemble (MIE) at Mills College be composed of equal numbers of women and men. The majority of its students have very different backgrounds and levels of institutional music training. Students range from having extensive formal training in music to being mostly self-taught. Their musical backgrounds include a diverse set of influences such as rock, jazz, classical, and Arabic music. In addition, students come from an unusually broad international pool, including students from South and Central America, Canada, Europe and Asia as well as the United States.

As the study of contemporary improvisation begins to take root in many different institutions around the world, Mills College offers its students a rare opportunity to investigate the reasoning behind such a program, the difficulties in creating and establishing one, and perhaps most importantly, the problems that may arise in attempting to create a program for studying a practice often viewed as being entirely "free" of pedagogical imperatives.

In this interview, much of my interest was to discover more about the rationale in creating a program dedicated to the study of contemporary improvisation. Much like jazz in the decades before, studying improvisation at an educational institution appears, at first, to be an absurd notion, if not a direct contradiction to the practice itself. In asking Fred Frith about the process of, reasons for, and intent behind creating this program of study, it is my hope that some of the questions and concerns about the institutionalization of improvisation (or even music study as a whole) will be further illuminated.

\section{C.C.: Why did you decide to create an improvisation degree at Mills College?}

F.F.: It was the result of a logical process. Mills has long recognized the importance of improvisation. After all, Terry Riley, Pauline Oliveros, Alvin Curran, and Anthony Braxton have all been on the faculty during the last twenty years, and current faculty Chris Brown and Maggi Payne, for example, are both actively involved with improvisation. I think a sea change occurred when they searched for someone to teach improvisation in the African-American tradition, which is now a fairly established academic post in institutions across North America, and found that it was difficult to fill the position. Perhaps the difficulty has become more acute with the de facto split between conservatives in the jazz world and the more dynamic and creative end of the tradition. I don't know. Anyway, the department felt compelled to re-open the search with a much broader definition of improvisation, which was when they invited me to join the applicant pool. Actually, I made it clear before I agreed to apply that I didn't feel either qualified or ready to teach improvisation located solely within the African-American tradition, so if that's what they were looking for they shouldn't ask me, and they, in turn, made it clear that they were no longer centering their search there. That, in itself, made it interesting to me as someone who grew up as an improviser situated somewhere between blues and jazz, rock improvisers like Pink Floyd and Grateful Dead, and contemporary music experimentalism. Anyway, I was not hired to start an improvisation degree but to teach improvisation, whatever that means. There was no agenda and no pressure to conform to a curriculum. I was basically left to get on with it. And my field of operations was broad from the beginning. The ensemble I directed did a lot of notated music and even songs, not only improvisation. I teach courses to undergraduates about film music and also about high culture/low culture issues in a "rock" course. I spend about an equal amount of time teaching composition. I am, after all, officially a professor of composition. No one's quite had the nerve to hire a professor of improvisation yet!

The degree developed a little later out of our understanding that there was a category of graduate applicants to Mills who didn't fit into either the Composition MA or the Performance MFA, which was totally grounded in European classical performance. Many who were primarily instrumental performers applied for the MA program but were clearly not "composers" in the traditional sense. And after a while, there were enough of them that we decided a new performance degree would make a lot of sense and allow us to admit talented individuals who otherwise didn't quite fit. As should be 
clear from the above, this was something that I helped to create based on a perceived need. The fact that the number of students in that category quadrupled within two years to the point where we can't really go any further without more resources should indicate the depth of that need.

C.C.: There has often been criticism (from both inside and outside the practice) that institutionalizing improvisation (creating degrees, programs, etc.) is contradictory to the ideology of improvisation. Do you think this is true?

F.F.: Well, first of all, that begs the question of whether "improvisation" is a single and identifiable genre with a universally understood ideology, which is debatable. I think that institutionalizing anything can have adverse effects, to the degree that academia is seen as a kind of self-sustaining mechanism tending towards the canonization of certain ideas at the expense of others. I've heard it argued that the primary role of professors of composition is to train future professors of composition to teach future professors of composition, for example. And the institutionalization of jazz certainly seems to have had the effect of reducing the scope of the music as it is officially sanctioned, generally making the milieu of that music thoroughly conservative in much the same way that the institutionalization of classical music has drastically reduced, rather than expanded the options or so it often seems from the outside. Frankly, all of the agenda-driven, ideological discourse surrounding improvisation doesn't hold much appeal for me. Not to say that it isn't important or necessary, more that it appears to unconsciously set up the very ossification that it's intended to avoid. George Lewis reportedly said that since all the things you can do as an improviser have now been done, the most interesting thing left to do now is to talk about it. I guess I haven't got there yet! I'm pretty pragmatic. I teach what I'm interested in, but I work with students on how to best realize what they are trying to achieve. I would imagine that's what most teachers do, actually. Since I never studied music formally - I have no degree in music at all-I had no real experience of how academic settings in music really function until I got here. And we're not exactly typical. I've taught classes, meanwhile, at SF State, UC Berkeley, UC Santa Cruz, UC Davis, UC Irvine, UC Denver, and at Stanford, so my horizons are a little larger than they were, but I can't pretend that I'm at all well-versed in the practices of academia or that I care much, one way or the other! Creating a degree and a program at Mills for improvising came about because there was an overwhelming demand for it.

In the end, improvising is what we all do. It's how we get through life, even within the rigid structures where we may have to work. Kids learn that they are musical by the fact of being able to make stuff up. When their talent is recognized, they are taught to do what they're told and follow a rather specific set of rules. I like to keep the focus on improvisation as the act of making stuff up. When you do it with other people, then all kinds of social aspects come into play, and mostly the qualities that make a good improviser are not dissimilar to the ones that I appreciate in my friends: being a good listener, sensitivity to your social surroundings, being there when you're needed but knowing how to step back too, knowing when to be supportive, when to be assertive, when your opinion is valuable, when to just go along with something, when to insist! Patience. Tolerance. Openness. The fact that l'm teaching in an institution is pretty much irrelevant to the way I work with improvisers; I focus on the same things when I work with them outside the institution.

I also think, though, having been here for seven years, that there are a lot of assumptions made about the "academic" setting that are peculiar. There was an article in Wire Magazine about Joanna Newsome, who was a student here, and the writer, who clearly didn't know much about Mills, said that she'd moved from the Music to the English Department because of the pressure to conform to a severe academic agenda imposed on her by Alvin Curran and Morton Subotnick and I! Well, you know, Subotnick was a student here a long time ago, but he actually teaches somewhere else, and Alvin and I never had any contact with Joanna at all, except in my case, regarding an audition for a scholarship for which I enthusiastically recommended her. So, this is a projection on the part of somebody who's decided what kind of environment an "academy" is, maybe because he went to one and was made to feel that way himself and never figured out that there may be other ways to do things! The same magazine also interviewed Deerhoof, who spoke of meeting in my composition class and of how much I encouraged them. So what is the reader supposed to believe? An institution can be what you want to make it, both teachers and students ...

C.C.: It is often the case that when music programs or styles become institutionalized, that they are usually said to become formulaic and so what made the music special in the beginning gets lost; one example of this is with jazz music programs in universities and conservatories. Is this also the case with improvised music? Is there any way of escaping this potential problem?

F.F.: Is it the "institution" that's the problem, or the agenda of the teachers who get the posts, or the kinds of people who want to have those posts? Or the concept of the "curriculum" as a means of demonstrating to the "consumer" (the student) a set of specific goals that you are aiming for them to attain in order to get good "grades," which makes for clarity of purpose but a tendency to allow teachers to rely on the same material so they don't have to constantly rework or rethink their courses; they can just wheel them out, year after year, without much critical reappraisal. I agree with Philip Tagg's observation that what is characteristic of the academy is that it revolves around the idea of a recognized "canon," which encourages comparison between institutions that are all seen as being basically on the same page. It encourages and rewards conformity to a certain degree, but maybe as a result, there are other institutions busy addressing this very difficulty. Mills is certainly one of them, but it isn't the only one. As long as teachers have a dynamic relationship with what they teach and are prepared to re-examine their own practice on a continuous basis, they will be able to engage their students. That's true of any subject, not just improvisation. It's far too early to say if the teaching of improvisation in academic settings will produce the kind of formulaic approach that you're talking about. It may, but I 
have a feeling that the kind of people who are interested in doing it are the ones most likely to resist allowing it to become formulaic! What I see, right now, is the establishment of "improvisation" as a sexy field for aspiring musicologists to make their mark and a way to create jobs for a certain breed of practitioner reared in an academic setting and wishing to remain there for life, if possible. I mean, we've had acousmatics, and electro-acoustics, computer music, and all the other branches of contemporary practice that, having been named, can spawn university departments, and conferences, and symposia, and festivals, and competitions, and other forms of respectability so that they, too, can be self-sustaining mechanisms to keep certain folk with creative energy and initiative alive and kicking. Is that so bad?

C.C.: It seems, then, that you believe institutionalized improvisation study does not necessarily have to become formulaic and, ultimately, detrimental to improvisation. Indeed, you believe institutionalized music study can create unique areas in which creation and change are not only possible, but are a common occurrence. Do you think the challenges and consequent solutions of improvisation pedagogy can be applied constructively to other areas of music study, including the scholarly study of music?

F.F.: Hmm. Did I say all that? Let's slow down here! Does institutionalized improvisation necessarily have to become formulaic and, ultimately, detrimental to improvisation? No, but it very well might, depending on the degree to which it is seen as a finite program with a clear-cut set of goals that can be taught by someone with the aid of a textbook or the equivalent thereof! Can institutionalized music study create unique areas in which creation and change are not only possible, but are a common occurrence? Why not? In my experience, being able to spend a long and focused period working with the same people in an open-minded and open-ended way can produce results, both fabulous and unforeseen. When I spent six months with "young unemployed rock musicians from the ghettos of Marseille" (as described by their own government program) we were able to do things at a level of sophistication that I could not achieve with the Ensemble Modern, brilliant musicians whose whole practice is rooted in the score. Show them a score and there's nothing they can't do. Without one it's hard work to keep their respect. Hardly any of the kids in Marseille could read music, so that was never an option. But we had time: not a few three-hour rehearsals but months of nine to five work and that demonstrated amazing possibilities. It wasn't in an "academic setting," but, in the end, that seems irrelevant, except in the important respect that they were being paid to work with me, not paying for the privilege! Anyway, you go to college, if you've got any sense, to find stuff out and to screw up (as often as possible) because that's how you learn, and when will you have that luxury again? If you have that attitude, finding "unique areas in which creation and change are not only possible, but a common occurrence" does not seem so unrealistic to me.

As for whether such creation and change are the result of "the challenges and consequent solutions of improvisation pedagogy" is a question with limited usefulness. Because if you believe that, then you're probably well on the way to codifying a practice which will then, no doubt, precisely inhibit the very creation and change it is supposed to encourage! As an improviser, I want to focus on being here, in this moment, in this place, with these people, and seeing what happens, what has happened, what will happen. Another moment with other people will neither have the same focus, nor the same meaning. I think the analysis of music has tended towards the idea that there is a "desire" on the part of a "composer," a "goal" that is realized using "this" set of techniques. Fair enough. But how do you apply that to a way of making music which is determinedly collaborative, which has no idea where it is going, which may be successful and disastrous in equal measure?

C.C.: What do you think the greatest problem is with teaching improvisation, a practice that is often thought of as entirely free and spontaneous?

F.F.: I had a student, a few years ago, who came into the MFA Performance program, the chamber music one. We didn't have an improvisation degree then, but she was really interested in improvisation, regarded it as an important thing to learn how to do. She took my graduate seminar on the history and practice of the interface of improvisation with composition in the last fifty years. We studied Indeterminacy, Earle Brown, Pauline Oliveros, Third Stream, Sun Ra, Braxton, Butch Morris, Zorn, Barry Guy, all kinds of different approaches and traditions. She was in my ensemble for two years, in which we tackled many improvisational pieces: Cardew's Treatise, Stockhausen's Aus den Sieben Tagen, my graphic scores, some Christian Wolff pieces, some pure improvisation, plus, Cecil Taylor came and worked with us, and also Leo Smith. Plus, she had a semester of improvisation workshops with Joëlle Léandre. Plus, she was a member of the informal Monday afternoon sessions that I run in my office, where a small group of regulars comes just to play.

Then she wrote her thesis on improvisation pedagogy and, basically, said that she found the lack of improvisation teaching very difficult, that she felt like she hadn't been taught how to improvise. I was fascinated by this; we talked about it a lot while she was writing the paper. And I understood that as a classical instrumentalist, there are certain practices that you learn and one of them is how to engage in constructive critical dialogue. You play a piece in front of peers, and your teacher and people tell you what they think you did wrong and how you can do better. They're all holding a score, so they have this reference where everyone can see how it's "supposed" to sound, and then they can point to particular deficiencies, either of reading, or interpretation, or of the technique required to realize a particular passage. It makes perfect sense and is a very important part of learning an instrument at a high level. So players get used to the idea that after playing in a pedagogical setting, there will be feedback that will help them understand what to do, feedback based on a more or less universal idea of what is "good" or "acceptable" in a given setting and what is "bad" or "unacceptable." And in the two years of fairly intensive study of improvising at Mills, she was still waiting for someone to tell her what to do, to tell her what was good and bad, and in the absence of that kind of feedback, her assessment was that she hadn't 
been "taught" anything. Whether she had learned anything is another question, but she hadn't got to that point, she was too busy feeling let down!

So if you want to know the greatest problem with teaching improvisation, maybe you should start right there! Who's defining the rules? Should there be any? And what happens if you break them? Is there "good" and "bad" in a universally accepted sense? How do you teach something that, at least nominally, has no accepted norms? I believe that all effective teaching is the act of facilitating the process of people teaching themselves. If your ego needs to be told, "I am the source of all wisdom, and I am telling you what is good and bad," then, at best, people will learn how to conform effectively to your taste and at worst feel inadequate and unappreciated. Is that teaching improvisation?

C.C.: That improvisation doesn't have any accepted norms has often been a point of contention. As you said, because improvisation doesn't really have a set external frame of reference (for example, a score), it often means statements made by different improvisers are taken by students to be absolute truths or that certain approaches are considered to be better than others. For instance, statements and opinions made by Eddie Prévost, Wadada Leo Smith, and Joëlle Léandre. While these perspectives aren't necessarily conflicting, it is often difficult to conceive of a means in which all of these perspectives are equally viable. How do you think the seemingly conflicting ideas surrounding improvisation should be or could be reconciled?

F.F.: I think conflict is very valuable. It's one useful way to progress. Reconciling conflict . . what do you mean by that I wonder? Coming to an agreement? Why is that necessary? As long as you proceed with mutual respect, you don't have to have identical opinions, feelings, or ways of doing things. It would be sad if we did. We all tend to be bundles of contradictions anyway, as we negotiate the shaky territory between our origins, our upbringing, our education, our social milieu, the way we wish to see ourselves and others to see us, our skill sets, our ambitions, our beliefs. Even as we are being radical and iconoclastic in our art, we may find ourselves behaving in a traditional way as teachers, reproducing the same mannerisms and methodologies that our own teachers adopted towards us. Same thing if you have kids, as any parent will tell you. Or we may get anxious about how "history" will see us and start "setting the record straight." There's all kinds of bullshit out there. It doesn't matter really. Those who learn from us usually take what they need, what makes sense to them, and discard the rest. That's how it should be. That's how we learned in the end. I don't see many believers in absolute musical truth knocking around the halls of Mills, you know. The only problem I see arising is when teachers or students start to get too self-important.

\section{C.C.: Do you think that improvisation is socially resonant? That it "teaches" methods and means of an ideal society?}

F.F.: Well, I talked about the values that are associated with a good improviser being not dissimilar to the ones you look for in your friends. But politically, that idea's been around for years. In the 70s, there were a lot of folks holding up improvisation as a superior democratic model because, you know, all the players were equal, there was no social hierarchy, no leader, no external authority like a score, and so on. Did that teach methods and means of an ideal society? You've got to be kidding! I remember reading a review of a performance of Berio's Sequenza for trombone in which it was cited as a great performance of the piece because the player actually ignored the score after a few bars and just improvised. Is that really cool or really arrogant? I had a friend who performed at an improvised music festival in Seattle, and she brought a music stand with her because they were going to play some particular piece or other. And the guy who was sharing the bill, a renowned improviser of some thirty years practice, was so upset that he threw the stand off the stage, because it didn't belong there, this was about improvisation. If you think that years of improvising will produce people who are not dogmatic, self-righteous, and intolerant, well, think again! There's always a danger whenever you start asserting that one form of musical practice is "better" than another on some sort of politico-social level. Every form of music is capable of being vibrant, dynamic, uplifting, and, needless to say, the opposite. I don't think that being a good improviser is going to make you a better person than if you are a good Baroque violinist or a good tabla player. Being a disciplined orchestral player is not somehow inferior to being an improviser. I've been improvising since I could walk, just like everyone else, and composing started not too many years after that. l've been doing both ever since. I regret not having had any formal training because there are certain things I don't know how to do. On the other hand, I've been testing my work in front of an audience since I was fourteen and working with wonderful musicians who have taught me, and continue to teach me, everything that I know as a musician. Some of them have been classical musicians, some are in the world of jazz, some deal with songs, some are improvisers. Have I learned less from Evelyn Glennie, or Katia Labeque, or Viktoria Mullova, or Werner Bärtschi, because they are "classical musicians"? Of course not! That level of virtuosity is totally inspiring, whatever the context you work in. Nobody spends too much time talking about how their chosen musical milieu represents an ideal society, nor claiming that their chosen field of operations is ideologically superior, at least not the people I hang out with.

C.C.: At Mills, you try to have an equal number of men and women in all aspects of the improvisation program, from the number of women in ensembles to the number of women that are in the program. Is there a particular reason for this?

F.F.: Well, it's not only Mills. If I'm doing a workshop somewhere, I always ask them to aim for that too. Because in my experience, if I don't, the overwhelming likelihood is that all but one or two of the participants will be male. It just keeps perpetuating the same old shit. I remember doing a workshop in Mexico City, and I had, as usual, asked for gender parity if possible. At a press conference beforehand, a journalist, a woman, asked if it was normal that all the workshop participants should be men. And I said, "of course not . . . very much the opposite, women are encouraged to 
participate." And she looked at me strangely and said, "Really?" like this was the first time she was hearing this. At the workshop there were fifteen men signed up, and then, she showed up with about twenty women friends! It was great! Biggest workshop I ever did!

Pauline [Oliveros] used to observe-when she was here — that Mills, being a women's college, the men who come into the graduate program should ideally consider themselves a privileged minority! Only problem was-and it was the first thing that struck me when I got here-was how few women there were in that program, so I mentioned it to Pauline and we decided to try and do something about it. And it has been a struggle, but we're getting closer to parity all the time. What I find extraordinary is how you can ask the question! Does it need a particular reason to afford women the same opportunities as men? l've been performing and collaborating with women on a regular basis for most of my professional life, and it pisses me off that there are fabulous, talented, brilliant women wherever I look but that whenever I play at major international festivals, the number of women in the program is still tiny. There are honorable exceptions, obviously, but still, I was having this conversation in the 70s. Isn't it time to stop talking about it and get on with addressing it? I played at the Music Unlimited Festival in Austria recently, and I was speaking to the pianist, Irene Schweizer, who l've known for over thirty years, and she said with great excitement that this was the first time she'd performed at a festival where there were more women than men on the bill and not only that, but nobody was congratulating themselves about it! That kind of tells you what you need to know, right? Personally, I think it's of an immediate and obvious benefit for men to work closely with women, even if it's only to rid themselves of the deeply ingrained understanding that men working with men is the norm. When it's no longer the norm, the problem will begin to disappear, I would hope. But that's secondary to the issue of making sure that all the opportunities are genuinely equal.

\section{C.C.: What value do you think theoretical and academic work in improvisation has for the discipline?}

F.F.: What is "theoretical work" in improvisation? People trying to figure out how it works and then codifying it? I think that has value in perpetuating the careers of professionals who like to do that kind of thing. But flippancy aside, I think we're back where we started. How is "academic" defined? For many, like that guy in Wire Magazine, it's clearly a pejorative word. You know, people who are cut off from the real world (where writers from Wire Magazine live) and pontificate from their ivory towers using words (that most of us don't understand) to discuss issues (that most of us don't recognize) while forcing their students to conform to criteria that most of us are disinterested in. And this caricature has nothing to do with my admittedly limited experience in the academic environment. What I see, daily, is a bunch of people, teachers and students, trying to figure stuff out. They do this in an engaged, critical, friendly, and passionate manner. Academic work in improvisation, in my neck of the woods, usually means a bunch of people improvising together, which makes it identical to non-academic work in improvisation. In the academy, we talk about it, we expose each other to different ideas about it, we practice it, we argue about it, and that's not any different from my ten years in Henry Cow, for example. So for me, nothing has changed really. I'm still just getting on with it, either at Mills or outside of Mills, it's the same.

\section{C.C.: How much involvement do you think scholars should have, then, with the practice of improvisation?}

F.F.: Not sure I understand the question. If they want to improvise, they should improvise. If they want to write about improvising, they should write about it. We're humans, therefore, we have an unlimited desire to quantify, sort out, categorize, statistify, and otherwise arrange the data that confront us. I don't have a problem with that as long as we acknowledge that there are some forms of understanding that have nothing to do with writing papers and reading them at conferences.

C.C.: How important do you think writing about improvisation is? What benefits can writing about improvisation have (including writing done by both performers and scholars)?

F.F.: It's important, if you have something useful to say and not, if you don't! Benefits would include illuminating different aspects of the practice, placing developments into a variety of historical and sociopolitical contexts, figuring out how different aspects of the practice work and, you know, all the rest of the things people write about. Not to mention its use in fostering and sustaining careers in universities! In my experience, there is an artificial divide between those who see themselves as scholars and those who see themselves as musicians. Many musicians I know have a vast range of scholarly knowledge about all kinds of aspects of their practice, but their scholarship may be looked down on in certain contexts because they haven't been educated in an academic way, they don't use the right terminology, they just don't fit into the agenda. Scholars are rather less likely to turn out to be great musicians. But it happens! In the end, it's all good, right? Now it's me stereotyping academia!

\section{C.C.: What advice do you have for musicians interested in entering into the world of contemporary improvisation?}

F.F.: Same advice I have for musicians entering any other field of endeavor or anyone else. Have fun, but don't waste your time. 